УДК $821.161 .1+821.111$

DOI: $10.17223 / 19986645 / 70 / 13$

\title{
И.О. Волков
}

\section{«ГАМЛЕТ» У. ШЕКСПИРА В ТВОРЧЕСКОМ ВОСПРИЯТИИ А.А. ФЕТА И И.С. ТУРГЕНЕВА (К 200-ЛЕТИЮ А.А. ФЕТА) ${ }^{1}$}

Разрабатывается аспект из истории творческих взаимоотношений А.А. Фета и И.С. Тургенева, связанный с именем У. Шекспира и трагедией «Гамлет». Подвергаются анализу произведения поэта (цикл «К Офелии» и близкие к нему стихотворения) $u$ писателя (рассказ «Гамлет Щигровского уезда»), которые, с одной стороны, стали результатом эстетического осмысления шекспировских образов (Офелия, Гамлет), с другой стороны, обозначили важные моменты непосредственного художественного взаимодействия.

Ключевые слова: А.А. Фет, И.С. Тургенев, У. Шекспир, «Гамлет», иикл «К Офелии», «Гамлет Щигровского уезда».

История личных и творческих взаимоотношений А.А. Фета и И.С. Тургенева составила огромное пространство культуры (см.: [1-3]), значимым элементом которого был в том числе У. Шекспир. Английский драматург стал одним из тех эстетических ориентиров, который продемонстрировал сближение и расхождение двух художников. Прежде всего это касалось природы словесного искусства и искусства вообще, принципов его связи с действительностью. Если Фет отстаивал позицию иррациональности творческого процесса, воспринимаемого им как проникновение в истину (красоту) через высокое откровение («Как самая поэзия - воспроизведение не всего предмета, а только его красоты, поэтическая мысль только отражение мысли философской и опять-таки отражение ее красоты; до других ее сторон поэзии нет дела») [4. Т. 3. С. 180], то Тургенев такому подходу отчаянно сопротивлялся. Он противополагал ему «сосредоточенное отражение» жизни [5. Т. 9. С. 396].

Разность суждений по поводу источника и свойства шекспировского дара можно считать одним из ключевых моментов этой полемики. Тургенев не принимал фетовского взгляда на Шекспира как художника стихийной, бессознательной деятельности, пытаясь указать на логически ясное представление драматургом своего творчества: «пора перестать хвалить Шекспира за то, что он - мол, дурак» [6. Т. 6. С. 164]. На это он не раз пенял Фету: «...мысленно рисую вас то с ружьем в руке, то просто беседующего о том, что Шекспир был глупец - и что, говоря словами Л.Н. Толстого, только та деятельность приносит плоды, которая бессознательна» [6. Т. 10. С. 62-63]

\footnotetext{
${ }^{1}$ Исследование выполнено при финансовой поддержке РФФИ в рамках научного проекта № 19-312-90006 «И.С. Тургенев и У. Шекспир: проблемы диалога».

${ }^{2}$ Во взгляде на Шекспира Фет словно наследует точку зрения Н.В. Станкевича и раннего В.Г. Белинского. Последний писал в статье «О русской повести и повестях
} 
Разность взглядов поэта и писателя обозначилась довольно рано и достаточно ясно, но споры продолжались - до «диких звуков славянской речи» [6. Т. 3. С. 149], продолжалось также и «со-творчество», в том числе «шекспировское». Фет и Тургенев в разное время с большим или меньшим успехом периодически примеряли на себя роль переводчика Шекспира. В этом плане в отношениях друг к другу у них сложились совершенно определённые позиции: первый был «практиком» перевода, а второй «теоретиком». Но именно Тургенев благословил Фета «на борьбу с Шекспиром» [6. Т. 3. С. 287] и помогал ему осваивать саму форму и содержание шекспировского стиха. Предметом особого внимания поэта и писателя явилась трагедия «Гамлет», которая в обоих случаях послужила источником вдохновения в рамках оригинального творчества. Знаменателен один момент: с чтения трагедии «Гамлет» в подлиннике и с попыток ее перевода на русский язык, не увенчавшихся успехом ${ }^{1}$, зачиналась творческая деятельность Тургенева. Та же перспектива обозначилась в ситуации Фета, но в обратном направлении: прекрасно освоив и усвоив трагедию принца Датского, поэт в конце своего долгого и плодотворного пути решается перевести ее с английского, однако далее первой сцены первого акта дело не двинулось: «В самом начале при появлении духа не справился со стихом Горацио: "Stay, speak. I charge thee, speak", который и не вмещается в русском стихе, и выходит безобразно» [8. С. 769].

Период 1840-х гг. стал для Фета и Тургенева временем завоевания литературного пантеона, тогда же проявил себя их насыщенный творческий интерес к трагедии о принце Датском, главные образы которой сделались основой художественной структуры отдельных поэтических и прозаических текстов. С 1842 по 1847 г. Фет написал одиннадцать стихотворений, эстетически осмысляемых им в непосредственной связи с шекспировской пьесой. Внешне и внутренне он оформил их в виде посланий к Офелии, создав в результате едва ли не лучшее поэтическое осмысление этого образа 2 .

Первые «офелиевские» стихотворения появились на страницах «Москвитянина» (№ 2) в 1842 г. - под подписью «А. Ф.» были напечатаны четыре текста («Не здесь ли ты легкою тенью...», «Стихом моим незвучным и упорным...», «Как майский голубоокий...», «Сосна так темна, хоть и месяц...») с объединяющим их названием: «Офелии». Далее из печати вышли еще четыре: в литературный сборник «Молодик» 1843 г. был включен «Горный ключ» с подзаголовком «Офелии», тогда же в «Москвитянине»

г. Гоголя (“Арабески” и “Миргород”)» (1835): «Когда поэт творит, то хочет выразить, в поэтическом символе, какую-нибудь идею, следовательно, имеет цель и действует с сознанием. Но ни выбор цели, ни её развитие не зависит от его воли, управляемой умом, следовательно, его действие бесцельно и бессознательно» [7. Т. 1. С. 288].

${ }^{1}$ О том, что Тургенев в конце 1830 -х гг. был занят переводом «Гамлета» (вероятно, некоторых отрывков), свидетельствуют пометы писателя в тексте трагедии (издание, подаренное Т.Н. Грановским в Берлине): аккуратные густые подчеркивания чернилами на протяжении нескольких страниц в пределах I (сцена 2-4) и II (сцена 2) актов.

${ }^{2}$ О цикле «К Офелии» см.: [9-12]. 
(№ 10) появилось стихотворение «Как Ангел неба безмятежный»; в «Репертуар и Пантеон» за 1846 г. (№ 2 и 10) попали тексты «Офелия гибла и пела» и «Прости» (последний - также с подзаголовком «Офелии»). Наконец, вне журнальных страниц оказались относимый к 1842 г. «Сонет (Офелии)» и датируемые 1847 г. стихотворения «Как идет к Вам чепчик новой...» и «Я болен, Офелия, милый мой друг».

Впервые возникшее в «Москвитяне» название «Офелии», объединившее в авторском замысле несколько поэтических текстов и придавшее им значение цикла, в дальнейшем станет непременным указанием на их общность и особую ассоциированность с героиней Шекспира. Усилив в этом заголовке элемент обращения («К Офелии»), Фет во всех трех поэтических сборниках $(1850,1856,1863)$ будет именно под ним публиковать свои «гамлетовские» произведения, варьируя их число. Этому же принципу последуют и издатели посмертного собрания («Лирические стихотворения», 1894). Наконец, в двухтомнике стихотворений Фета, составленном Б.В. Никольским в 1912 г., в цикл «К Офелии» будут объединены все поэтические тексты (всего - четырнадцать), включающие в себя имя шекспировской героини или когда-либо появлявшиеся под его знаменем (исключение составили три: «В альбом», «Как гений ты, нежданный, стройный...» и «Я говорил при расставаньи...», не получившие от автора прямого соотнесения с Офелией).

Практически в унисон с Фетом работает над собственным прозаическим «циклом», материалом к которому избирается трагедия Шекспира, Тургенев. В 1844 г. он создает рассказ «Андрей Колосов», где герой, подобно Гамлету, пытается осмыслить и объяснить для себя происходящую в нём «борьбу разнороднейших ощущений» [5. Т. 4. С. 19], дать анализ движению своих чувств в ситуации сомнения - между долгом и неспособностью (бессилием) его исполнить. Через три года в печати появляется рассказ «Петр Петрович Каратаев» (1847), в котором была отчетливо проведена параллель с Шекспиром, закрепленная на уровне эпиграфа из «Гамлета» и цитат-декламаций. Историю своего героя Тургенев осмысляет как драму и внешне основывает ее на столкновении человека с несправедливой действительностью, а также резкой несочетаемости его притязаний и положений реальности. Гамлетовский текст в обоих случаях послужил раскрытию сложной внутренней дисгармонии современной личности. Наконец, в 1849 г. выходит рассказ «Гамлет Щигровского уезда», ставший для писателя концептуальным выражением проблемы «русского Гамлета». Именно в пространстве этого текста впервые осуществился творческий диалог Тургенева и Фета, основанный на специфике понимания трагической истории Датского принца вообще и образа Офелии в частности.

Постепенно создавая стихотворный цикл «К Офелии» и осмысляя его в этом качестве, Фет был непосредственно погружен в атмосферу эстетического восприятия «Гамлета» - постановку трагедии на московской сцене в переводе Н.А. Полевого и в исполнении П.С. Мочалова. В воспоминаниях «Ранние годы моей жизни», хотя отдаленных от эпохи $1840-$ х гг. большим 
промежутком, Фет достаточно точно воспроизводит свое впечатление от игры актера и дает определенное представление о собственном понимании главной проблематики произведения.

Фет видел в Гамлете «...слабое нерешительное существо, на плечи которого сверхъестественная сила взвалила непосильное бремя, который за постоянной рефлексией желает скрыть томящую его нерешительность» [13. С. 158]. Такая трактовка со всей очевидностью восходит к точке зрения И.В. Гёте, назвавшего шекспировского героя (устами Вильгельма Мейстера) «прекрасным, чистым, благородным, высоконравственным созданием, лишённым силы чувств, без коей не бывает героев», гибнущим «под бременем, которое ни нести, ни сбросить ему не дано» [14. С. 199]. Однако Фет, соглашаясь с концепцией немецкого поэта, стремится углубить и укоренить возникшее противоречие. Констатируя вслед за Гёте слабость Гамлета перед внешними силами - долг чести в отмщении («великое деяние, тяготеющее над душой, которой такое деяние не по силам»), он указывает на его «непосильное внутреннее страдание» [13. С. 158]. То есть, по его мысли, на героя давит не только «бремя судьбы», но и чрезвычайность вызванных им душевных перипетий.

Под таким углом зрения Фет рассматривает и сценическую игру Мочалова, не находя в ней соответствия действительной тяжести мук, испытываемых Гамлетом. Его недовольство вызвала страстность исполнения, не соответствующая заданной роли: «Мочалов искал не воспроизведения известного поэтического образа, а только наиболее удобного случая показаться пред публикой во всю ширь своей духовной бесшабашности» [13. С. 158]. Точно так же с субъективной манерой актера в свое время не соглашался и В.Г. Белинский, порицавший его за то, что он «придал Гамлету гораздо более силы и энергии, нежели сколько может быть у человека, находящегося в борьбе с самим собою и подавленного тяжестью невыносимого для него бедствия» [7. Т. 2. С. 328]. Признавая за Гамлетом «тяжесть невыносимого бедствия», непонятого Мочаловым, критик «сущность содержания и развития» шекспировской трагедии связывает с «внутренней борьбой её героя с самим собой» [7. Т. 5. С. 21]. Такой взгляд вновь сближает Фета с Белинским, однако последний избегал крайности в утверждении слабости Гамлета, обязательно противопоставляя ей «величие души» («велик и силен в своей слабости») [7. Т. 2. С. 293].

Позиция Тургенева, прошедшего серьезную критическую школу немецкого и французского шекспироведения и пришедшего к концу 1840-х гг. к целостному представлению о трагедии Гамлета ${ }^{1}$, была во многом близка фетовскому взгляду. Писатель также кладет в основание своей интерпретации гётевское объяснение заявленных драматургом противоречий («дуб посажен в драгоценный сосуд») [14. С. 199], но, соглашаясь с А. Шлегелем, слабости Гамлета противопоставляет масштаб его ума, который дал немецкому критику повод назвать произведение Шекспира «еin

\footnotetext{
${ }^{1}$ Подробнее см.: [15. С. 90-103].
} 
Gedankenschauspiel» (драмой / театром мысли) и сравнить его с «Фаустом» [16. С. 148]. Пассивность героя Тургенев объясняет грандиозной сложностью его характера: он «бездействует вследствие нерешительности, сомнения и размышления» [6. Т. 1. С. 378]. Выдвигая на первый план рефлексивную природу Гамлета («Рефлектировать значит по-русски: “размышлять о собственных чувствах”») [5. Т. 1. С. 224], писатель в её понимание вкладывает драматический масштаб неразрешимых противоречий.

От внимания Тургенева также не ушла фигура Мочалова в качестве сценического интерпретатора известного художественного образа. Не случайно он вкладывает упоминание о нем в уста Петра Каратаева, который и переходит к сбивчивому чтению стихов из «Гамлета» именно благодаря памяти об этом актере. «Жаркая» декламация, мимика и жесты героя («И лицо Каратаева побледнело, глаза беспокойно забегали; он отвернулся; легкие судороги пробежали по его губам» [5. Т. 3. С. 238]) несут на себе отпечаток страстной натуры Мочалова в роли принца Датского. При этом автор, цитируя те места трагедии, что были критически отмечены Белинским, делает каратаевское исполнение явно субъективным: его манера проистекает из внутренней драмы, глубины собственных чувств - это та особенность личного пристрастия, что была отмечена Фетом в мочаловской игре: «Он не играл роли героя, влюбленного в Офелию или в Веронику Орлову ${ }^{1}$ : он действительно был в нее безумно влюблен» [13. С. 158].

Иронически воспроизводя выступление Мочалова в полупьяных речах Каратаева, Тургенев таким образом сходится с Фетом в оценке гамлетовского поведения артиста как тенденциозного, но тем не менее он отдает должное его таланту. Позже, в речи по поводу юбилея Шекспира, писатель отметил: «Или образ Гамлета не ближе, не понятнее нам, чем французам, скажем более - чем англичанам? Не соединилось ли для нас навсегда с этим образом воспоминание о величайшем русском - именно русском актере, Мочалове?» [5. Т. 12. С. 327]. «Магическое действие его игры», «власть очарователя, заставлявшего своим язвительным шепотом замирать весь театр сверху до низу» [13. С. 157] признает в своих воспоминаниях и Фет.

От понимания сути трагических перипетий, происходящих в пьесе Шекспира, и проблематики ее главного характера, ставшего их воплощением, Фет шел к усвоению образа Офелии, относимого им к числу идеалов из области «явлений невозможных, которых отчизна непостижимая бездна человеческого духа» [4. Т. 4. С. 76]. В этой драматической фигуре поэт видел отражение сложности гамлетовского состояния, упрощенную Мочаловым в сценическом исполнении. Чтобы четко прочертить глубину мятущейся души героя, Фет в воспоминаниях приводит в пример именно изменившееся поведение принца в обращении со своей невестой - существом

1 Прасковья Ивановна Орлова (1815-1900), артистка московского театра (1835$1845)$, партнерша П.С. Мочалова и исполнительница роли Офелии. Называя ее «Вероникой», Фет, вероятно, путает настоящее имя со сценическим - в пьесе Н.А. Полевого «Уголино». 
чистым и невинным. Для него принципиально важно, что «ироническихолодное отношение Гамлета к Офелии явилось не вследствие какого-либо проступка со стороны последней, а единственно потому, что, со времени рокового открытия, ему не до мелочей женской любви» [13. С. 158]. В представлении Фета бедная девушка оказывается жертвой внутренней дисгармонии принца, забывшегося в своем страдании. В качестве контрастного непонимания этого факта он вновь приводит игру Мочалова, который «страстно любит свою Офелию и терзает ее от избытка любви» [13. C. 158].

Прочтение этого женского образа Фет сочетает с его художественной интерпретацией, результатом чего и явился цикл «К Офелии», ценность и самостоятельность которого в своем поэтическом наследии он всегда отстаивал. В одиннадцати стихотворениях одного десятилетия поэт с помощью Шекспира выражает лирические переживания, связанные с темой любви, при этом важную непосредственную роль в оформлении основного предмета играет природа.

Из всех поэтических текстов наиболее тесную сюжетную связь с трагедией «Гамлет» и историей Офелии имеют два, прямо называющие имя героини Шекспира: «Офелия гибла и пела» и «Я болен, Офелия, милый мой друг». Своим содержанием они обращаются к одному и тому же моменту шекспировской пьесы, а именно смерти невесты Гамлета, запечатленной в рассказе Гертруды (акт IV, сцена 7). В первом стихотворении Фет в несколько измененном виде цитирует трагедию в переводе Н.А. Полевого:

Перевод Н.А. Полевого

Офелия плела венки и пела.

$<\ldots>$

Все пела и венки свои плела,

Пока ее одежда не промокла,

И бедную не повлекло на дно

[17. C. 173].
A.A. Фет

Офелия гибла и пела, И пела, сплетая венки; С цветами, венками и песнью На дно опустилась реки

[4. T. 1. C. 134].

Сюжет гибели Офелии выстраивает печально-меланхолическую перспективу, на которой предельно кратко разворачиваются лирикофилософские размышления, подчиненные любовной линии. Песни умирающей девушки, постепенно и навсегда пропадающие в речной воде, ассоциируются с атрибутами сердечного чувства («слезы и мечтания»), входящими глубоким впечатлением в душевный мир человека («канет / Мне в душу») [4. Т. 1. С. 134]. Шекспировский текст оформляет неоднозначность восприятия любви, приводя общую тональность стихотворения к нотам грусти, ощущению утраты и разочарования. Поэт закрепляет это звучание словами «канет» и «темное дно», которые становятся доминантами поэтического настроения.

На подобный лирический лад настроено и другое стихотворение Фета «Я болен, Офелия, милый мой друг!», уже первой строкой обращенное к героине Шекспира. Диалог с Офелией происходит в тех же координатах 
тревожного предчувствия и любви, осмысляемой как «болезнь» (ср. слова: «Я болен, я влюблен; но, мучась и любя» в более позднем (1854) стихотворении Фета «Какое счастие: и ночь, и мы одни!») [4. Т. 1. С. 223]. Основой поэтического созидания становится предшествующая гибели девушки сцена ее появления в безумном состоянии (акт IV, сцена 5), которое выдают произносимые ею песни. Она поет о «милом друге», «в страшной он лежит в могиле» [17. С. 157] - именно на эти слова трагедии (и снова в переводе Полевого) откликается Фет: «О, спой мне, как носится ветер вокруг / Его одинокой могилы» [4. С. 133]. Лирический герой понимает и принимает душевную скорбь, терзающую Офелию. Ее любовная тоска, выходящая на поверхность только в помешательстве, находит сочувственное выражение в собственном реальном состоянии: «Душе раздраженной и груди больной / понятны и слезы и стоны» [4. С. 133].

Не останавливаясь только на плаче безутешного сердца, поэт движет сопереживание в шекспировской градации, в результате которой в стихотворении появляется образ ивы: «Про иву, про иву зеленую спой» [4. С. 133]. Этот символ вносит в текст мортальный аспект: развешивая цветочные венки именно на иве, растущей у обрывистого берега, Офелия срывается и падает в реку. Прося и даже требуя столь горестно-тяжелых нот, герой Фета усиливает минорное звучание в направлении любовной темы. Это происходит за счет привлечения другой трагической истории из Шекспира: «...спой, / Про иву сестры Дездемоны» [4. С. 133]. Развивая образ ивы, поэт в одном переживании соединяет две судьбы, в которых любовь и смерть оказываются неразделимы, и присоединяет к ним ощущения лирического «Я». Именем Дездемоны, поющей незадолго до собственной гибели о девушке, отвергнутой любимым ${ }^{1}$, Фет закольцовывает композицию стихотворения, утверждая его двойственный смысл. При этом в передаче песни героини он использует слова не из перевода «Отелло» И.И. Панаева 1836 г., а из рукописного переложения Н.П. Огарёва (в письме к Т.Н. Грановскому от 18 апреля 1843 г.) $)^{2}$, известного узкому дружескому кругу: «Пойте про иву зеленую!» и «Пойте про иву, про иву, про иву!» [19. С. 20].

К этой паре стихотворений, наиболее близко подошедших к осмыслению трагедии невесты Гамлета, можно также причислить «Горный ключ» и «Прости», у которых в подзаголовке прямо приведено имя Офелии. В первом тексте связь с печальной судьбой девушки объемно вырастает через образ водного потока. Горный ключ, ассоциированный с рекой, в которой утонула Офелия, получает у Фета глубокое философское осмысление в соседстве с чрезвычайной живописностью. Метафорически, через красочные определения ручей (так он назван и в переводе Полевого) в ли-

\footnotetext{
1 «Согласно народным представлениям эпохи Шекспира, плакучая ива была эмблемой девушки или женщины, покинутой любимым человеком» [18. С. 567].

2 Посылая перевод песни Дездемоны в письме к Грановскому, Огарев выполнял просьбу Н.X. Кетчера, занятого проектом издания полного собрания драматических сочинений Шекспира (в прозе). Огарев перевел для него также стихотворные вставки из «Гамлета»: песни Офелии и могильщика.
} 
рическом мгновении оказывается своеобразным центром существования, соединяющим небо и землю («Гордо носил бриллианты / Скромно листы и цветы») [4. Т. 1. С. 326], день и ночь («Был при деннице румян ты, / Был при луне бледен ты») [4. Т. 1. С. 326], человека и природу («Тучи несут тебе воду, / Чуждые люди дары») [4. Т. 1. С. 327]. На протяжении четырех строф рисуется образ подвижной и меняющейся водной стихии, поражающей своей красотой и жизненной силой.

Когда в это описание включается голос лирического героя, горный ключ получает параллель с течением времени, неумолимым и уносящим вспять все, что попалось ему на пути. Он вдруг называется «чадом тревожной неволи» [4. Т. 1. С. 327] - в соответствии с душевным расположением вступающего с ним в диалог субъекта. Свое тягостное самоощущение герой переносит на крутой поток, который оказывается способен и к тому, чтобы заключить в себе конкретные символы его переживаний («Что же мне бросить в поток? / Кубок ли звонкий, кольцо ли») [4. Т. 1. С. 327]. Таким знаком делается «роза увядшая» с «жёлтым листком»- предмет из счастливой поры прекрасного чувства, ныне ставший бременем памяти. Но избавление от него не приносит облегчения, напротив, потеря увеличивает муку: «Чувство, и зренье, и слух мой / Гибнут с последним цветком» [4. T. 1. C. 327].

Стихотворение «Прости» («Прости, - я помню то мгновенье...»), тематически исполненное в форме прощания и просьбы прощения, неявно отсылает к разговору Гамлета и Офелии в первой сцене третьего акта. Это знаковый эпизод, в ходе которого принц под грузом свалившейся на него задачи жестоко отвергает любящую его девушку и признается в своей нелюбви к ней. Именно эту сцену называл Фет в «Воспоминаниях», приводя искажающую игру Мочалова и имея в виду язвительно-бесстрастное поведение Гамлета по отношению к Офелии. Поэт создает в лирическом исполнении несостоявшееся объяснение двух любящих героев, в котором от лица шекспировского персонажа произносятся столь же решительно, но с мягкостью понимания и сострадания слова прощания. При этом в стилистику стихотворения органично встраивается пушкинская традиция: параллель поэтического признания создается не только очевидностью первой строки («...я помню то мгновенье») [4. Т. 1. С. 345], но и всей логикой деликатности последующего объяснения.

Фет соединяет воспоминание о «чудном мгновении» с тяжестью вынужденного прощания. Как и у Пушкина в стихотворении «Я Вас любил: любовь еще, быть может...», лирический герой выказывает здесь свое благородство, избегая лишней аффектации и притворства («Я ложью не хочу коварной / Младому сердцу говорить») [4. Т. 1. С. 345]. Точно так же в конце звучит своеобразное напутствие-пожелание с верой в лучшее («Еще пышней, еще прекрасней / Одна - коль силы есть - цвети!») [4. Т. 1. С. 345]. Но если у Пушкина расставание выглядит вполне естественно ввиду угасающего чувства, имеет свою закономерность в прошедшей влюбленности (вероятно, безответной), то Фет оставляет недосказанность 
относительно истинной причины разрыва. Любовь как таковая не подвергается сомнению или отрицанию (в отличие от Гамлета: «Я любил тебя прежде! <..>> я не любил тебя!») [17. С. 100], а единственный произнесённый комментарий: «Давно ты видела, я верю, / Как раздвояется наш путь») [4. T. 1. С. 345], - дает повод думать о существовании между влюбленными внешней преграды. Намекает на это и признание героя: «Забыть тяжелую потерю / Я постараюсь как-нибудь») [4. Т. 1. С. 345]. Именно как давление надличностной силы трактовал Фет невольный поступок (или проступок) Гамлета по отношению к Офелии - это (уже цитированное) «роковое открытие», которое не позволяет ему вникнуть в «мелочи женской любви». Не случайно в стихотворении дважды звучит мотив безумия («Мою безумную любовь»; «душою благодарной, / Хоть и безумной») [4. T. 1. С. 345] - это еще одно проявление гамлетовской бессознательности в поведении лирического героя. Наконец, его грустное и беспристрастное «последнее прости» можно сопоставить с глубиной сожаления принца Датского у могилы Офелии, где он произносит: «Но я любил ее, как сорок тысяч братьев / Любить не могут!» [17. С. 189].

В других стихотворениях, входящих в означенный цикл или стоящих в непосредственной близости от него, Фет, практически не выстраивая непосредственной параллели между сюжетом трагедии и своим, выбирает разные способы для осмысления шекспировского образа и проблематики чувства. Например, в таком качестве выступает тема творчества, к которой можно отнести «Сонет» с подзаголовком «Офелии» и стихотворение «Стихом моим незвучным и упорным». В обоих поэтическая форма становится средством воспроизведения «порывов души».

Сонетный стих, которым «владеть всего труднее» [4. Т. 1. С. 330], уподобляется сложности выражения тех ощущений, что овладевают человеком в состоянии влюбленности. Тактовое звучание строк и их рифмованное сочетание служат средством гармонизации, упорядочения множества впечатлений и поиска ответа на вопрос: «За что я полюбил» [4. Т. 1. С. 330]. Лирическое «Я», обращаясь к объекту своих чувств и мечтаний, открыто, но безымянно сравнивает его с Офелией: «...Бог в тебе осуществил / Передо мной создание поэта» [4. Т. 1. С. 330]. И форма, и содержание стихотворения в своем единстве апеллируют к музыкальному «созвучию сонета» Шекспира, позволяющему проявиться движениям души и набросать нежный образ. Освоение «причудливой» формы совершается одновременно с движением к высшему воплощению любви - «чувству красоты», утверждением которого становится заключительный терцет. Важно заметить, что, предполагая связь с шекспировским сонетом, Фет не следует его системе рифмовки, оставаясь в пределах французского образца.

Если сонет однозначно мыслится как идеальная поэтическая материя для выражения чувственно-прекрасного, то обычный стих - «незвучный и упорный» вначале вызывает сомнение своей способностью быть носителем душевной импрессии: «Напрасно я высказывать хочу...» [4. Т. 1. 
С. 323]. В этом случае лирическая форма нацелена не столько на передачу, сколько на получение отклика на свое звучащее содержание: «...пламенную веру / В душе твоей возбудит тайный стих» [4. Т. 1. С. 323]. Стихотворный метр берет на себя функцию вызвать понимание воспринимающей родственной души: «...размеру / Она должна сочувствовать на миг» [4. Т. 1. С. 323], - так как он существует в тех же пределах высокого и невесомого, трогательного и нежного. Поэзия стиха определяется как один из главных ориентиров в поиске взаимности, сопереживания в связи с предельной близостью к сфере чувственного и чувствительного, и именно это приводит лирического героя к уверенности: «Да! Ты поймешь, поймешь я это знаю» [4. Т. 1. С. 324].

В аспекте акта творчества как процесса воссоздания сердечных впечатлений и передачи сокровенных мечтаний, поиска отклика на них можно также рассматривать стихотворение «Как майский голубоокий...». Здесь медиатором души оказывается воздушная арфа, с которой она прямо сравнивается. Чрезвычайная чуткость душевного восприятия уподобляется струнам, поддающимся дуновению ветра, который, в свою очередь, оказывается живым веянием - «дыханием твоим» [4. Т. 1. С. 133]. Игра на арфе в результате становится лирической эмблемой взаимодействия чувств, когда нежный порыв одного сердца в направлении другого отзывается преображенным, но столь же прекрасным стремлением. При этом поэт дополнительно вкладывает в свою ассоциацию эстетическую память о Жуковском, называя музыкальный инструмент именно «Эоловой арфой».

Отсылая к одноименной балладе 1814 г., Фет в похожей лирической ситуации юной любви, символом которой является мелодия струн, особенно сближается со своим предшественником в мотиве вечности чувства и связанного с ним звучания: «Но вечно под чувством живым, / Найдет она новые звуки» [4. Т. 1. С. 133]. В литературную традицию, повлиявшую на «Эолову арфу» Жуковского, входил в числе прочих и Шекспир, герои которого - Ромео и Джульетта просматриваются в Минване и Арминии [20. С. 458]. Стихотворение Фета тоже не лишено возможности такого соотнесения, но поэт, изначально включая его в цикл «Офелии» (1842), настаивает на «гамлетовском» ореоле, причем лишенном трагизма. Здесь для него важны те лирические черты, что запечатлены у Шекспира в образе чистого и нежного существа.

В гораздо большей степени близость с Жуковским в тесной связи с Шекспиром проявилась у Фета в трех стихотворениях, осмысленных им в 1847 г. как поэтическое единство: «Не здесь ли ты легкою тенью...», «Сосна так темна, хоть и месяц...» и «Как Ангел неба безмятежный...». Все тексты объединены мотивом ангела или ангела-гения, восходящим к поэтическому символу «таинственного посетителя» Жуковского. Тема встречи, форма прямого обращения и разговора-беседы, медитативный настрой, а также пейзаж в его подвижном состоянии - все это оказывается генетически соотнесено с поэтической системой русского романтика, а именно с его «эстетическим манифестом» «К мимо пролетевшему знакомому гению» (1819) и образом «Гения чистой красоты». 
«Гений-посетитель» особенно явно отзывается в стихотворении «Не здесь ли ты легкою тенью», оно строится словно пунктиром по программному тексту Жуковского. Лирический герой Фета замечает рядом с собой присутствие («легкую тень») [4. Т. 1. С. 132] знакомого образа и обращается к нему, чтобы удостовериться в подлинности своего ощущения. Точно так же вопрошает поэт у Жуковского, он пытается отгадать природу своего видения-впечатления, причину его посещения, сознавая при этом давнее с ним знакомство. Ряд развернутых риторических вопросов становится формой разговора с «прилетевшим гением». Они раскрывают «минуты былтия», которые переживает человеческая душа и которые всегда преисполнены тайного присутствия высшей духовной силы. У Фета герой ограничивается лишь одним вопросом, ему важно знать только, что перед ним именно его «ангел-друг», но далее открывается та же риторическая последовательность, емко показывающая свойства «моего гения»:

И робким даришь вдохновеньем,

И сладкий врачуешь недуг,

И тихим даришь сновиденьем...

[4. T. 1. C. 132]

Однако если для Жуковского гений-посетитель - это всегда обитатель горних высей, то Фет делает его сродственным с лирическим героем; «пленитель безымянный» у Жуковского в последней строке получает название «ангел-хранитель души» [21. Т. 2. С. 148], что закрепляет его небесную, покровительственную сущность. Фет же, как в начале и середине стихотворения, в обратной градации повторяет: «Как гений, как ангел, как друг» [4. Т. 1. С. 132], настаивая на непосредственной близости «собеседников», осененной чувством любви.

Воспринимая и перенимая у Жуковского образ «моего гения», «ангела души», Фет уменьшает его многозначность и сосредоточивается на тех его воплощениях, что связаны с вечной женственностью и чувствительностью сердца в их эстетическом откровении. Поэта интересует поэзия прекрасного в мгновенном, сиюминутном переживании и в форме чистой любви. Он идет по пути Пушкина в воплощении своего идеала - не приземленного, но и не надчеловеческого, в который и входит Офелия Шекспира.

Так, стихотворение «Как Ангел неба безмятежный...» наследует уже прозвучавшую идею Жуковского об «ангеле-хранителе», имеющей у него отчетливый религиозно-поэтический смысл. Но Фет на равную позицию с божественным откровением ставит также категорию чувственнопрекрасного, конкретно женственного. Он строит свой текст не столько как благоговейное вслушивание-всматривание лирического героя в явившийся перед ним таинственный образ, сколько как обращение к возлюбленной, представляемой в виде ангела. Поэтому лексика высокого порядка («Ангел неба», «сияние огня», «тихими крылами», «молитвы») соседствует с обозначениями конкретности живого чувства: «душою нежной», «любви 
словами», «сердие», «твоей» [4. Т. 1. С. 134]. В безответный разговор героя с предметом своего обожания Фет вложил рисунок тех слов Гамлета, что завершают его знаменитый монолог «Быть или не быть»: «Милая Oфелия!.. О нимфа! / Помяни грехи мои в молитвах!..» [17. С. 100]. Все стихотворение, по сути, оказывается и просьбой, обращенной к любящему существу, и самой молитвой, главное содержание которой связано с желанием любви, уверенности в ее силе и взаимности.

Риторическим выражением «сильной любви» с обращением к «моему ангелу» оканчивается стихотворение «Сосна так темна, хоть и месяц». Две заключительные строки («Мой ангел, мой ангел далекий, / Зачем я так сильно люблю?») [4. Т. 1. С. 133] оказываются единственным аккордом, который выражает чувство лирического героя к далекой избраннице. Однако это признание подготавливается и предваряется панорамой полночного пейзажа в проблесках месяца. Пейзажная насыщенность, за которой и вследствие которой возникает неосязаемый образ возлюбленной, играет здесь примерно ту же роль, что и у Шекспира. Фет столь же крепко основывает происхождение «ангела далекого» на природном комплексе, как и Офелия в трагедии прочно погружена в ряд важных флористических символов.

Картина природы, наполненная звуками, запахами, зрительными образами и представленная в состоянии изменчивости, чередования (с помощью союза «то... то...»), также хранит в себе след поэзии Жуковского «зримой и вещественной в своей сюжетно-описательной основе» [22. С. 148]. Но если лирический наблюдатель, например, в элегии «Славянка» (1815) движется сам и объемлет своим восприятием все то реальное, что входит в сферу его непосредственного чувствования, то у Фета, во-первых, это полотно наполовину воображаемое, создаваемое в «сладкой дремоте» [4. Т. 1. С. 133]; во-вторых, все сиюминутные впечатления не столько собираются их случайным (или неслучайным) свидетелем, сколько самостоятельно вторгаются в его восприятие, нарушают сон и мечту.

Появление цикла «К Офелии» принято объяснять (или дополнять) помимо глубины усвоенного литературного источника - еще и обстоятельствами биографического характера. Считается, что лирическая рефлексия Фета в сторону кроткой и чистой любящей женской души могла быть вызвана впечатлениями юности, а именно увлечением неизвестной молодой особой, которая находилась в крестном родстве с А.А. Григорьевым. С последним Фет был очень близок в студенческие, а также в последующие годы и, по всей видимости, разделил с ним предмет своей влюбленности. Хотя в воспоминаниях о раннем периоде жизни Фет никак не отразил этот эпизод, исследователи находят очевидный намек на него в поэме «Студент» (1884), где в роли возлюбленной фигурирует девушка по имени Лиза.

В качестве еще одного материала в «расследовании» сердечных волнений и склонностей юного поэта используют повести Григорьева об Арсении Виталине. Особенное внимание из этой прозаической серии привлека- 
ет «ультраромантический» [11. С. 45] очерк с названием «Офелии». Здесь Григорьев в дневниковой форме рассказывает историю мещанской девушки Лизы, только перешагнувшей порог между детскостью и расцветом юности. Автор дает ей право называться Офелией в связи с произошедшим с ней несчастьем любви, в котором она сама оказывается повинна. Героиня сначала весело пренебрегает первым и искренним чувством в пользу выгодного замужества («человек с состоянием и офицер») [23. С. 160], а затем с горечью сознает свою ошибку, исправить которую уже нет возможности.

История «бедной Офелии», как несколько раз называет героиню рассказчик, находит отчетливые контуры схождения со стихотворением Фета «Как идет к вам чепчик новый», открывавший цикл в сборнике 1850 г. Как и в повествовании Григорьева, «мещанская драма» нарисована поэтом в тех же двух контрастных планах. Первая часть стихотворения в восклицательноприподнятом тоне представляет героиню через обыкновенно-бытовой план, связанный с материальными предметами - «обновой»: «Как идет к вам чепчик новый, / Как идет большая шаль!» [4. Т. 1. С. 132]. После этого неожиданно звучит комментарий лирического героя: «А мне все-таки вас жаль» [4. Т. 1. С. 132] - хотя не слишком навязчивый, но заставляющий задуматься о существовании подтекста, скрытого смысла в предшествующих словах восхищения-поздравления. Далее тональность начинает разниться еще резче, и внешние приметы сменяются проявлениями болезненного состояния: «Как идет вам эта бледность, / Эта скрытая печаль» [4. T. 1. С. 132]. В этих словах заключена двойственность оценки, поскольку причину «бледности» и «печали» можно трактовать как в положительном, так и в отрицательном русле. Последующее указание на «внутреннюю бедность» вносит ясность в позицию героя и его отношение к той, к кому он обращается. Наконец, заключительные строки: «Мне вас жаль, да, мне вас жаль» [4. Т. 1. С. 132] звучат своеобразным приговором, в них - разочарование и осуждение, переходящие в прощание.

Текст Григорьева делает понятным основу лирического переживания и дихотомию женского образа. Показательны в этом отношении слова из последнего абзаца его повести: «...потребность любви заменялась в ней жеманным развратом, свободная грация - наглостью кокетки дурного тона, жажда наслаждений - привычкой к пустой и непорядочной суетности» [23. С. 167]. В результате присутствие этого стихотворения в цикле Фета на первый взгляд справедливо кажется странным и не совсем уместным - так отличается созданный в нем женский облик от его последующей совокупной характеристики. Однако в этом несходстве нужно учитывать логику собственно авторского осмысления, идущую от чувств и переживаний героя, испытавшего эволюцию в построении идеального образа.

Стихотворения «шекспировского цикла» Фета были известны Тургеневу, с одной стороны, по печатным публикациям, центральную часть которых составил «Москвитянин», с другой - в устной форме, явленной на литературно-музыкальных вечерах и в творческом кругу «людей 1840-х гг.». 
Знакомство с ними, как и вообще с фетовскими сочинениями, писатель никак не маркирует - ни в произведениях, ни в письмах, ни в воспоминаниях вплоть до весны 1848 г., когда создавался рассказ «Гамлет Щигровского уезда». Именно в этот текст входят поэтические строки Фета, потенциально усиленные звуками голоса и музыки. Тургенев делает их частью проявлений загадочно-меланхолической природы своей героини, которая в минуты сердечной тоски исполняла романс «На заре ты ее не буди». Автором мелодии к стихотворению Фета был композитор А.Е. Варламов, которому также принадлежала музыка к театральной постановке «Гамлета» в 1837 г.

Создавая рассказ «Гамлет Щигровского уезда» и помещая уже в его названии ссылку на известный литературный источник, Тургенев сознательно не искал внешних средств для как можно более точного соотнесения своей «степной драмы» с трагедией Шекспира. Художественноэстетическая связь между двумя произведениями основывалась им на установлении драматической доминанты рассказа - как со стороны жанровой структуры, так и в образно-сюжетном отношении. Общим звеном в этом построении, наряду с главным героем, оказывается образ молодой девушки Софьи, значимо соотнесенной именем и драмой судьбы с шекспировской Офелией.

Разворачивая свою исповедь, герой Тургенева в качестве одного из важнейших этапов жизни (после «кружка») представляет историю женитьбы и первых лет семейного «блаженства». Эта часть его биографии вводит темы любви, природы и смерти. Он рассказывает «с жаром» о «существе благороднейшем, добрейшем», «существе любящем и способном на всякие жертвы» [5. Т. 3. С. 266]. Воспоминание о Софье качественно разделяется на две части - романтическую и прозаическую. Первая соответствует его представлениям о ней как о необыкновенной девушке, в которую он влюбился, о которой «думал или более мечтал» [5. Т. 3. С. 267]. Пора прекрасного чувства «по справедливости» оценивается героем как трогательная «чуть не до слез», в ней нет «ни малейшей горечи», хотя до этого, в самом начале его рассказа, проскользнула ироническая оценка: «...женился дома на чахоточной барышне, лысой, но весьма замечательной личности» [5. T. 3. С. 266, 257].

Передавая свое душевное состояние, он воссоздает окружавшую его тогда атмосферу, в основе которой - явный контраст, характеризующий также и противоречие его собственного состояния. Подаваемая в явно насмешливой окраске заброшенная, застарелая, даже одичалая обстановка дома Софьи (сад и беседка, гостиная) с кажущимися столь же «заглохшими» приметами романтического быта (альбомы, портреты, бюсты Шиллера и Гёте, немецкие книги) напрямую соседствует с картиной прекрасного вечера на террасе. Это природное изображение соответствует лучшим мгновениям душевных переживаний героя, составляющих светлую страницу его жизни. Здесь соединяются едва намеченные элементы пейзажа, культуры и повседневности, но без какого-либо противоречия между ними, в полном согласии и взаимной сочетаемости: 
Я глядел тогда на зарю, на деревья, на зеленые мелкие листья, уже потемневшие, но еще резко отделявшиеся от розового неба; в гостиной, за фортепьянами, сидела Софья и беспрестанно наигрывала какуюнибудь любимую, страстно задумчивую фразу из Бетховена; злая старуха мирно похрапывала, сидя на диване; в столовой, залитой потоком алого света, Вера хлопотала за чаем; самовар затейливо шипел, словно чему-то радовался; с веселым треском ломались крендельки, ложечки звонко стучали по чашкам; канарейка, немилосердно трещавшая целый день, внезапно утихала и только изредка чирикала, как будто о чем-то спрашивала; из прозрачного, легкого облачка мимоходом падали редкие капли... А я сидел, сидел, слушал, слушал, глядел, сердце у меня расширялось, и мне опять казалось, что я любил [5. Т. 3. С. 268].

Эта картина романтической, даже сентиментальной идиллии из прошлого связана в сознании «щигровского Гамлета» с пониманием и признанием истинности своей любви. Хотя в настоящем он так и не может ответить себе, любил ли он Софью [5. Т. 3. С. 268]. В эту неопределенность героя автор вкладывает свою трактовку чувств, испытываемых Гамлетом к Офелии. У Шекспира колеблющийся вопрос любви остаётся открытым на длительном протяжении пьесы и даже в финале из уст самого героя не получает явственного положительного ответа. Способность Гамлета любить Офелию Тургенев поставил под сомнение и прямо сказал об этом в статье «Гамлет и Дон Кихот» (1860). По его мнению, Датский принц настолько сосредоточен в пределах своей личности, что в этом всепоглощающем эгоизме не оставил места для чувства иного рода, которое предполагает привязанность к другому человеку.

Однако атмосфера прекрасного, соответствующая эстетике Фета, в которую слиты воедино подвижные впечатления сиюминутного - свет и цвета вечерней природы, звуки задумчивой музыки, знаки уютного быта, оказывается способом проявления чистоты внутренних ощущений героя рассказа. Значительно замечание, которое он делает в направлении собственных чувств: «...сердце у меня расширялось» [5. Т. 3. С. 268]. Эта экзальтация восходит к «распространению души», запечатленной Жуковским в статье о «Сикстинской Мадонне» Рафаэля ${ }^{1}$, наблюдение которой стало для поэта «счастливым часом жизни» [21. Т. 12. С. 343]. Именно в свете этого «счастья жизни» «щигровский Гамлет» приходит к осязанию любви, которое далее, под грузом обыденности и страданий мира, а также собственного эгоизма, навсегда теряется.

Вторая часть воспоминаний о Софье в исповеди тургеневского героя строится уже в ином направлении. Мажорные аккорды первых свиданий и радостного движения души сменяются минором. Невеста, которую «степной Гамлет» отличал от всех других «обыкновенных уездных барышень», предстает в его глазах всё тем же «добрым, умным, молчаливым» существом «с теплым сердцем» [5. Т. 3. С. 267-268]. Однако при близком с ней

\footnotetext{
${ }^{1}$ Собственные впечатления от «Сикстинской мадонны» Рафаэля изложил и Фет - в письмах «Из-за границы» (1856) и стихотворении «К Сикстинской мадонне» (1883).
} 
знакомстве он обнаруживает, что «у ней на дне души» «сочилась ранка, которую ничем невозможно было излечить» [5. Т. 3. С. 268]. Таинственная рана явилась причиной столь же необъяснимой меланхолии девушки, ее пребывания в тихом и печально-задумчивом состоянии, как бы отстраненном от действительности семейной жизни. Неизвестная травма души указывает на случай чрезвычайного потрясения в прошлом. Несмотря на то, что герой «собрал справки: ничего не оказалось» [5. Т. 3. С. 269], он, однако, и в настоящий момент думает о том, что произошло что-то страшное, навсегда отпечатавшееся в самой глубине ее внутреннего мира. Василий Васильевич не случайно сравнивает «ранение» Софьи с тем, как когда-то его чиж попал в лапы к кошке и, хотя спасённый, навсегда перестал петь: «и она так же дулась и чахла, как мой несчастный чиж» [5. Т. 3. С. 268].

Глубокое душевное переживание девушки, впоследствии закончившееся гибелью, наводит на аналогию с Офелией, потрясение которой также привело к печальному исходу. Личная трагедия лишила ее жизненной опоры и опрокинула все представления о ясном и разумном устройстве окружающего. Такого масштаба последствий для своей Софьи Тургенев, конечно, не предполагал, но вслед за Шекспиром он показывает, как печальная судьба девушки отпечатывается на общем трагическом мироощущении героя, а также задает вопрос о степени вины его в произошедшей гибели.

Тургенев в пандан Шекспиру делает Софью столь же чуткой к колебаниям внешнего мира, поэтому, очевидно, замужество, вырвавшее ее из круга привычных вещей и представлений, обострило скрытую болезнь души. Символично в этом плане предшествующее сравнение с канарейкой в клетке. Несвобода прирученной певчей птицы проецируется на судьбу Софьи, для которой семейная жизнь с Василием Васильевичем стала вынужденным заточением. Подтверждают это и слова самого героя: «Иногда ей самой, видимо, хотелось встрепенуться, взыграть на свежем воздухе, на солнце да на воле; попробует - и свернется в клубочек» [5. Т. 3. С. 268].

«Безымённая тоска», которой томилась Софья, внешне имела те же проявления, что до этого служили романтическими атрибутами как патриархальной запущенности родительского дома девушки, так и возвышенного упоения героя в период знакомства. Ироническое и идиллическое теперь воспринимается Василием Васильевичем в едином русле - как «привычки старой девицы» [5. Т. 3. С. 269], лишь увеличивающие его собственные муки. Однако в перечне этих рутинных «трафаретов» («Бетховен, ночные прогулки, резеда, переписка с друзьями, альбомы») [5. Т. 3. С. 269] вдруг появляется именно тот лирический текст Фета, что был положен на музыку и превращен в романс. «Степной Гамлет» сетует, что «замужняя женщина» предавалась тихой грусти и пела по вечерам «На заре ты ее не буди». Цитируя в рассказе первую строку фетовского стихотворения, Тургенев при этом меняет местами два первых и два последних слова, в результате чего получается: «Не буди ты ее на заре».

Эта перестановка, часто воспринимаемая как неточность или ошибка писателя, на самом деле является знаком его эстетической рефлексии. Тур- 
генев ничего не исключает, не заменяет ни одного слова, даже трехстопный анапест обходится без усечений и нарушений, но он по-своему организует интонационную картину стиха. В результате перемещения начала и конца строки под логическим ударением оказываются слова: «не буди», что дает новое (по сравнению с оригиналом) прочтение. Такой акцент соответствует нравственно-психологической составляющей исповеди главного героя. «Не буди» - это, с одной стороны, усиление фетовских нот сострадания, обращение к «щигровскому Гамлету» с призывом не рушить гармонию покоя, не тревожить в порыве эгоизма и без того угнетенную душу, погруженную в романтический сон. С другой стороны, здесь очевиден намек на бездействие самого героя, который - при всем понимании происходящего и стремлении к объективной оценке - «на серединке остановился».

Используя начало фетовского стихотворения в собственной аранжировке, Тургенев с первой строкой вносит в свой текст и всю его образно-смысловую составляющую. Оно оказывается словно отражением внутреннего состояния Софьи, характеризующегося тем же болезненным томлением.

В элегическом рисунке Фета явлен хрупкий женский образ, погруженный в настроение тревожного предчувствия. Лирическая героиня представлена в двух состояниях - утреннего сна и вечернего бодрствования, но автор не делает между ними различия в эмоционально-психологическом плане. Стремящаяся вникнуть в загадочный мир сумеречной природы, она отвечает ему щемящим сочувствием, в котором нарастает что-то взволнованно-печальное, таинственно-томительное, мучительно-беспокойное. Лунный свет, то пробивающийся сквозь движущиеся тучи, то скрывающийся за ними, не в силах прояснить окружающую темноту, откуда столь же таинственно доносится пение соловья, но это не привычные трели, а именно «свист и урчание» [4. Т. 1. С. 169], вероятно отдающиеся эхом. Чем больше героиня погружается в этот притягательно-загадочный мир за окном, тем сильнее подступает к ней собственное волнение: «Все бледней становилась она, / Сердце билось больней и больней» [4. Т. 1. С. 169]. Объясняя беспокойными впечатлениями прошедшего вечера необходимость сна и не допуская его прерывания, поэт, однако, в описании спящей девушки использует те же «неспокойные» краски. Сон, хотя и «сладкий», не способен принести облегчения, это лишь состояние временного забвения, не избавляющего от существующей горечи. Ему даны определения «горячий» и «утомительный», намекающие на то, что он не принесет с собой свободу и отдохновение, а оставит после себя еще бо́льшую усталость и нездоровый жар.

Поэтически запечатленный Фетом облик девушки, страдающей как физическим, так и душевным недугом, Тургенев воссоздает в прозе. Краткой жизненной истории Софьи писатель придал те же загадочномеланхолические черты, выразил тот же мотив медленного угасания нежного и кроткого существа. При этом стихотворение «На заре» закономерно вводит вслед за собой в структуру образа тургеневской героини 
также лирический строй цикла «К Офелии». Тургенев явно или неявно пересекается с романтической поэтикой Фета «шекспировского» свойства.

Форма фетовских стихотворений представляет собой лирическую исповедь героя. Это не имеющие и не требующие ответа обращения к «прекрасной даме», в которых проговариваются заветные мысли и чувства, всегда связанные с темой любви. Их вполне можно сравнить с эстетической формулой Жуковского: «Посол души, внимаемый душой» [21. Т. 2. C. 135]. Переживания лирического героя выстроены живописной галереей нравственно-психологических движений его внутреннего мира: здесь грусть и разочарование, тревожное предчувствие и сомнение, болезненность и боль, тоска и скорбь, утрата и прощание, смерть. Хотя поэтическое мироощущение включает в себя также моменты радости, наслаждения, безмятежности, его магистральная линия все же имеет четкое меланхолическое направление. Но эта лирическая меланхолия не безнадежная и не беспросветная, она подчинена образу прекрасного, красоты, за счет которого вообще и оказывается возможным ее существование.

Герой Фета, безусловно, не является Гамлетом, однако в нем заключено то же стремление высказать все впечатления души, возникающие в текущий момент; представить их стройным рядом получается не всегда, поскольку сама суть их имеет нечеткий («воздушный») рисунок - это лишь мгновение, полноту которого запечатлеть невозможно - и здесь вновь Фет сходится с Жуковским в желании «выразить невыразимое».

Наконец, особая роль отводится природе, с помощью которой и в диалоге с которой «неподвластная выражению» поэтическая экспрессия, эстетическая рефлексия находят способ не только явить себя, но и выстроить путь к восприятию и пониманию.

Тургенев во многом действует в тех же координатах, используя голос Гамлета, чтобы дать герою возможность высказать себя. Исповедь Василия Васильевича, мучительно требующая своего слушателя, столь же нестройна и насыщенна. В ней преимущество тоже отдано нотам уныния и грусти (разочарования), хотя общий комплекс оттенков звучания очень велик. Однако если у Фета печаль всегда прекрасна, всегда опоэтизирована и связана с идеалом, то Тургенев в пространстве прозаического мира обнаруживает течение подлинно трагического. Неизбывная драма человеческой жизни не имеет разрешения, у нее нет выхода к искомой гармонии, но есть возможность сопоставления со столь же вечной и непоколебимой силой природой. Такую нравственно-философскую концепцию Тургенев ярко воплощает через тему смерти в воспоминании героя о похоронах Софьи.

Эта сцена дописывалась писателем после окончания чернового автографа, он разрабатывает ее на последней странице рукописи, когда уже поставил свою подпись, знаменующую завершение замысла. В небольшом абзаце, занявшем нижнюю часть листа, сказывается особенная кропотливость авторской работы, в ходе которой вводятся и уточняются все важные детали: конкретизируется церковная обстановка, развивается облик священника, укрупняются знаки природного топоса. 
Изображение похоронной службы четко делится на две части. Первая - это описание небольшой приходской церкви, которое собирается в перечислении ее одиноких и обветшалых примет (почернелый иконостас, голые стены, выбитый кирпичный пол), среди них не выделяются даже «большие старинные образы» [5. Т. 3. С. 269], идущие в общем перечислении. В самый центр этого бедного убранства, устало хранящего присутствие религиозного благочестия, помещен гроб, несущий на себе тот же отпечаток деревенской неустроенности: он стоял «пред царскими дверями», одетый «полинялым покровом» [5. Т. 3. С. 269]. Звучащий здесь очевидный контраст остается практически незамеченным, он затеняется продолжением описания, которое представляет все в той же тональности уже собственно церковную службу. Посреди скудной обстановки совершают свое действо, как некую рутину, два старых служителя: дьячок и священник, их облик и движения даны в полном соответствии с общей печально-осиротелой атмосферой.

Второй план изображения составляет рисунок весенней природы, которая словно врывается своей радостно-живительной силой в разомкнутое с помощью открытых окон пространство церкви. В знакомой логике легкой штриховки писатель вводит ее минимальные признаки, тем не менее составляющие в своем единстве небольшую, но живописную картинку. Атмосфера скорбного обряда разряжается проникновением в его границы лепета «молодых, свежих листьев плакучих берез» и «травяного запах» [5. T. 3. С. 269]. Над точностью в передаче этих природных образов Тургенев работает особо. Так, он дважды называет листья молодымми и дважды вычеркивает это слово, впоследствии все же восстанавливая, а рядом записывает варианты: круглье, зеленые, свежие [24. Л. 7 об.]. Волнует писателя и четкость в представлении берез: в столбик он перечисляет и тут же зачеркивает три прилагательных: молодые, плакучие, старые [24. Л. 7 об.]. Только помещенное между двумя контрастными признаками слово «плакучие» переходит в беловой автограф, что знаменательно: сознательно или нет, но именно этим определением Тургенев вносит дополнительный шекспировский акцент. В широком плане он связан с подчеркнутой скромностью и даже бедностью похорон Софьи, что, конечно, отсылает к погребению Офелии, которую также «с неполным торжеством хоронят», но все же «по-христиански» [25. С. 204], хотя к этому послужили иные причины. Плакучая береза же, под которой писатель подразумевает совершенно конкретный и характерный для национального ландшафта вид растения с ниспадающей кроной, отсылает к плакучей иве Шекспира. При этом Тургенев избирает для своего природного символа противоположный смысл: свисающая с березы «лепечущая» листва - это знак вечной жизненной силы, который противостоит смерти. Шекспир же поместил иву с ее «предательскими» ветвями в единый с Офелией мортальный комплекс. Однако оба художника следовали одной и той же задаче - поэтизации как отдельного образа, так и всей ситуации.

Художественные средства трагедии, обусловленные законом жанра, не могли предоставить Шекспиру возможности создания пейзажа в объемно- 
описательной форме. Тургенев, напротив, обладающий такими инструментами, не воспользовался ими, предпочтя широким многоцветным линиям тонкую рисовку, но в обоих случаях по намеренно расставленным деталям собирается целостный природный образ. Идеально вобрал флористическую фрагментарность Шекспира и живописно ее воплотил английский художник Дж.Э. Милле в картине «Офелия» (1851-1852). Тургенев, конечно, писал свой рассказ вне ее контекста (за три года до создания и официальной выставки полотна), но она вполне отвечала его эстетическим представлениям.

«Травяной запах», проникающий в церковь, тоже оформился у писателя не сразу, на полях рукописи он первоначально записывает: «со двора несло запахом <нрзб> сена» [24. Л. 7 об.]. Изменение предмета обоняния повлияло и на цветовую палитру - единство и преобладание ярко-зеленых красок природного мира, вносящего свежесть и молодость. Дополняется и завершается пейзаж «веселым светом весеннего дня», в котором бледнело «красное пламя восковых свечей» [5. Т. 3. С. 269]. Снова контраст, демонстрирующий превосходство простоты степной природы над религиозным обрядом. Это противопоставление повторится далее - в описании того, как «...в золотой пыли солнечного луча проворно опускались и поднимались русые головы немногочисленных мужиков, усердно молившихся за покойницу» [5. Т. 3. С. 269]. Границы церковного все более размываются, и искреннее сочувствие крестьян, кладущих поклоны, получает внерелигиозный облагораживающий компонент.

Последним знаком «вторжения» естественного мира в богомольную атмосферу становится голос птиц: «...воробьи так и чирикали на всю церковь, и изредка раздавалось под куполом звонкое восклицание влетевшей ласточки» [5. Т. 3. С. 269]. Предельно простые и хорошо узнаваемые звуки весеннего расцвета и благоденствия, как доносящиеся из-за стен деревенского храма, так и раздающиеся внутри них, словно провозглашают торжество природы. Но оно «затеяно» не для того, чтобы развенчать сам смысл проводимой похоронной службы, а с целью противопоставить конечности человеческой жизни природную вечность. В этом проявлена жизнеутверждающая позиция автора: примирить с неприглядной действительностью и со скорбными процессами, происходящими глубоко внутри, смягчить трагичность мироощущения, в том числе и трагедию смерти, хотя снять её совсем невозможно. Именно в такой логике звучат итоговые слова «щигровского Гамлета» по отношению к Софье: «Я глядел на мертвое лицо моей жены... Боже мой! и смерть, сама смерть не освободила ее, не излечила ее раны: то же болезненное, робкое, немое выражение, - ей словно и в гробу неловко...» [5. Т. 3. С. 269] Но даже к этому «вечному» отпечатку страдания он считает необходимым добавить сочувствие: «Горько во мне шевельнулась кровь. Доброе, доброе было существо, а для себя же хорошо сделала, что умерла!» [5. Т. 3. С. 269-270].

Таким образом, Фет и Тургенев практически одновременно обозначили в своем творчестве целую «эпоху» эстетического осмысления Шекспира, 
что особенно ярко проявилось в интерпретации трагедии «Гамлет» и двух ее главных образов. Фет подошел к Шекспиру с позиции «чистого искусства», поставив в 1840-е гг. в центр своего прочтения фигуру Офелии, в которой через поэтическую рефлексию лирического героя воплотилась идея чувственно-прекрасного женского образа. Результатом эстетического построения стали одноименный цикл, а также тесно связанные с ними стихотворения, исполненные в единой романтико-импрессионистической тональности. Тургенев, одновременно с поэтом работая в русле прозаического воплощения гамлетовского образа, дает свою интерпретацию «русской Офелии». В рассказе «Гамлет Щигровского уезда» он моделирует драматическую фигуру экзальтированной провинциальной барышни, подверженной тайной меланхолии. Принцип тургеневского изображения основан на его двупланности, в соответствии с которой в одном образе сливаются черты высокопоэтические и обытовлённо-иронические. Чтобы придать образу силу драматического звучания, Тургенев прибегает к поэтическому опыту Фета.

Спустя пять лет после публикации рассказа «Гамлет Щигровского уезда» и через два года после установления в Спасском дружеских отношений с Фетом, Тургенев наряду с другими сотрудниками «Современника» принимается за издание нового собрания стихотворений поэта, собственноручно исполняя роль его «главного редактора». В 1856 г. такая книга вышла, но состав ее претерпел существенные изменения по сравнению со своей предшественницей: около половины стихотворений было исключено, а из оставшихся бо́льшая часть приняла иной вид [26. С. 564]. Подвергся значительным сокращениям и цикл «К Офелии», в который вошли только три стихотворения: «Не здесь ли ты легкою тенью...», «Я болен, Офелия, милый мой друг!..» и «Как Ангел неба безмятежный...». При этом из первого стихотворения был изъят последний катрен, а во втором слово «око» заменено на «мысль». Судить о том, в какой мере на такой состав цикла повлияло решение именно Тургенева, невозможно, поскольку нет достоверных свидетельств всех этапов его редакторской работы. При этом, оценивая результат конечных правок, точно можно сказать, что их автор стремился к тому, чтобы прояснить смысл стихотворений, придать им большую однозначность и однонаправленность. Единство цикла в прежнем составе складывалось из разнородности и смены ракурсов откровения лирического героя. В новой редакции вместе с текстами исчезло и их многоголосое сочетание.

\section{Лuтература}

1. Лотман Л.М. Тургенев и Фет // Тургенев и его современники. Л., 1977. С. 25-49.

2. Курляндская Г.Б. Тургенев и Фет // А.А. Фет: Традиции и проблемы изучения. Курск, 1985. С. 46-62. 
3. Генералова Н.П. А.А. Фет и И.С. Тургенев: Незавершенный спор // А.А. Фет: Проблемы изучения жизни и творчества. Курск, 1994. С. $23-43$.

4. Фет А.А. Сочинения и письма : в 20 т. СПб., 2006. Т. 3. С. 180.

5. Тургенев И.С. Полное собрание сочинений и писем : в 30 т. Сочинения : в 12 т. М., 1978-1986.

6. Тургенев И.С. Полное собрание сочинений и писем : в 30 т. Письма : в 18 т. М., $1989-$

7. Белинский В.Г. Полное собрание сочинений : в 13 т. М., 1953-1959.

8. Переписка А.А. Фета с великим князем Константином Константиновичем (К.Р.) // А.А. Фет и его литературное окружение. М., 2011. Т. 103, кн. 2. С. 590-978.

9. Козубовская Г.П. О поэтике цикла А. Фета «К Офелии» // Русская поэзия XVIIIXIX вв.: (Жанровые особенности. Мотивы. Образы. Язык.). Куйбышев, 1986. С. 88-99.

10. Боброва О.В. Цикл А. Фета «К Офелии»: (к проблеме текстологической организации цикла) // А.А. Фет и русская литература. XV Фетовские чтения. Курск ; Орел, 2000. C. $177-181$.

11. Кочелев В.А. «Я болен, Офелия...» (К истории лирического цикла) // А.А. Фет и русская литература. Курск, 2003. С. 35-60.

12. Федотов О.И. Гамлет и Офелия как лирические герои в русской поэзии XIXХХ вв. // Горизонты гуманитарного знания. 2018. № 4. С. 80-142.

13. Фет A.А. Ранние годы моей жизни. М., 1893. 548 с.

14. Гёте И. В. Годы учения Вильгельма Мейстера // Собр. соч. : в 10 т. М., 1978. Т. 7. C. $7-504$.

15. Волков И.О. Уильям Шекспир в художественном мире И.С. Тургенева («Гамлет» и «Король Лир») : дис. ... канд. филол. наук. Томск, 2019. 369 с.

16. Schlegel A. Über dramatische Kunst und Literatur. Vorlesungen. Heidelberg, 1817. Teil 3. $440 \mathrm{~S}$.

17. Шекспир У. Гамлет / пер. Н.А. Полевого. М., 1837. 207 с.

18. Морозов М.М. Избранные статьи и переводы. М., 1954. 593 с.

19. А.Г. [Герцен А.А.] Из переписки недавних деятелей: (Материалы для истории русского общества) // Русская мысль. 1889. № 12. С. 12-21.

20. Семенко И.М. Примечания // Жуковский В.А. Собр. соч. : в 4 т. М. ; Л., 1959. T. 2. C. $451-485$.

21. Жуковский В.A. Полное собрание сочинений и писем : в 20 т. М., 1999-.

22. Янушкевич А.С. В мире Жуковского. М., 2006. 523 с.

23. Григорьев А.А. Воспоминания. Л., 1980. 437 с.

24. ОР РНБ. Ф. 795. Ед. хр. 9. Л. 1-7 об.

25. Шекспир У. Гамлет / пер. А.И. Кронеберга. М., 1861. 234 с.

26. Бухштаб Б.Я. Судьба литературного наследства А.А. Фета // Литературное наследство. М., 1935. Т. 22-24. С. 561-602.

Hamlet by William Shakespeare in the Artistic Perception of Afanasy Fet and Ivan Turgenev (To the 200th Anniversary of the Birth of Afanasy Fet)

Vestnik Tomskogo gosudarstvennogo universiteta. Filologiya - Tomsk State University Journal of Philology. 2021. 70. 233-256. DOI: 10.17223/19986645/70/13

Ivan O. Volkov, Tomsk State University (Tomsk, Russian Federation). E-mail: wolkoviv@gmail.com

Keywords: Afanasy Fet, Ivan Turgenev, William Shakespeare, Hamlet, cycle "To Ophelia", "The Hamlet of the Shtchigri District".

The reported study was funded by the Russian Foundation for Basic Research, Project No. 19312-90006: I.S. Turgenev and W. Shakespeare: Problem of Dialogue.

The article covers a fragment from the history of relations between Afanasy Fet and Ivan Turgenev connected with the name of William Shakespeare and the tragedy The Tragicall 
Historie of Hamlet, Prince of Denmarke. In the dialogue of the two Russian writers, the English playwright was the subject of lively aesthetic conversations and disputes related to the principles of artistic comprehension of the real world and understanding of the laws of verbal art. In addition, at different times, Fet and Turgenev tried on the role of Shakespeare's translator with more or less success. In their own poetry and prose, in the 1840s, Shakespeare found individual reflections, in which priority was given to the tragedy Hamlet and its central characters. Fet and Turgenev read the story of the Prince of Denmark with equal relevance, but gave it slightly different interpretations. For Fet, the tragedy of Shakespeare's character lays in the depth of internal suffering that arose due to the unbearable hardships of fate, while Turgenev saw its basis in an extreme moral and psychological contradiction. With these differences, the writers' concepts grew from a single source - Goethe's interpretation of Hamlet's image. One of the main manifestations of the suffering nature of Hamlet for Fet was the tragic fate of Ophelia. Giving it universal significance, he poeticized it in eleven poems created in the period from 1842 to 1847 , which, in different compositions and at different times, he combined into the cycle "To Ophelia". Hamlet's bride, as Fet interprets, embodies the idea of a sensually beautiful female image depicted in a single romantic-impressionistic tonality, and also associated with the poetic tradition of Vasily Zhukovsky and Alexander Pushkin. Turgenev actively perceived the image of Fet's Ophelia: the writer used the intonations of this lyrical character in the image of his Sophia from the story "The Hamlet of the Shtchigri District" (1849). Entering into a dialogue with the poet and including the first line of Fet's poem "At Dawn" in his story, Turgenev endows the brief life history of a village girl with similar mysterious and melancholic properties. The description of Sophia's fate is made in a tangible elegiac tone with a steady growing movement towards drama. In accordance with the law of Shakespeare's ambivalence, together with lofty features, Turgenev does not avoid the usual prosaic features in the image, which, however, does not break its lyrical integrity. Turgenev and Fet agree on the desire to give their images a universal human meaning, which is also achieved with the help of a natural text of poetical and philosophical content.

\section{References}

1. Lotman, L.M. (1977) Turgenev i Fet [Turgenev and Fet]. In: Alekseev, M.P. (ed.) Turgenev $i$ ego sovremenniki [Turgenev and his contemporaries]. Leningrad: Nauka. pp. 25-49.

2. Kurlyandskaya, G.B. (1985) Turgenev i Fet [Turgenev and Fet]. In: Golle, G.E. (ed.) A.A. Fet: Traditsii i problemy izucheniya [A.A. Fet: Traditions and Problems of Study]. Kursk: Kursk State Pedagogical University. pp. 46-62.

3. Generalova, N.P. (1994) A.A. Fet i I.S. Turgenev: Nezavershennyy spor [A.A. Fet and I.S. Turgenev: Incomplete dispute]. In: A.A. Fet: Problemy izucheniya zhizni i tvorchestva [A.A. Fet and I.S. Turgenev: Incomplete dispute]. Kursk. pp. 23-43.

4. Fet, A.A. (2006) Sochineniya i pis'ma: v $20 t$. [Works and letters: in 20 volumes]. Vol. 3. St. Petersburg: Folio-press.

5. Turgenev, I.S. (1978-1986) Polnoe sobranie sochineniy i pisem: $v 30$ t. Sochineniya: $v$ $12 t$. [Complete works and letters: in 30 volumes. Works: in 12 volumes] Moscow: Nauka.

6. Turgenev, I.S. (1989-cont.) Polnoe sobranie sochineniy i pisem: v 30 t. Pis'ma: $v 18$ t. [Complete works and letters: in 30 volumes. Letters: in 18 volumes]. Moscow: Nauka.

7. Belinskiy, V.G. (1953-1959) Polnoe sobranie sochineniy: $v 13 t$. [Complete works: in 13 volumes]. Moscow: USSR AS.

8. Fet, A.A. (2011) Perepiska A.A. Feta s velikim knyazem Konstantinom Konstantinovichem (K.R.) [Correspondence of A.A. Fet with Grand Duke Konstantin Konstantinovich (K.R.)]. In: A.A. Fet i ego literaturnoe okruzhenie [A.A. Fet and his literary environment]. Vol. 103 (2). pp. 590-978.

9. Kozubovskaya, G.P. (1986) O poetike tsikla A. Feta "K Ofelii" [On the poetics of A. Fet's cycle "To Ophelia"]. In: Russkaya poeziya XVIII-XIX vv.: (Zhanrovye osobennosti. 
Motivy. Obrazy. Yazyk) [Russian poetry of the 18th-19th centuries: (Genre features. Motives. Images. Language)]. Kuybyshev. pp. 88-99.

10. Bobrova, O.V. (2000) Tsikl A. Feta "K Ofelii": (k probleme tekstologicheskoy organizatsii tsikla) [A. Fet's cycle "To Ophelia": (to the problem of the textological organization of the cycle)]. In: A.A. Fet i russkaya literatura. XV Fetovskie chteniya [A.A. Fet and Russian literature. XV Fet Readings]. Kursk; Orel. pp. 177-181.

11. Koshelev, V.A. (2003) "Ya bolen, Ofeliya..." (K istorii liricheskogo tsikla) ["I am sick, Ophelia..." (To the history of the lyric cycle)]. In: A.A. Fet $i$ russkaya literatura [A.A. Fet and Russian literature]. Kursk. pp. 35-60.

12. Fedotov, O.I. (2018) Hamlet and Ophelia as Lyrical Heroes in 19th and 20th Century Russian Poetry. Gorizonty gumanitarnogo znaniya. 4. pp. 80-142. (In Russian).

13. Fet, A.A. (1893) Rannie gody moey zhizni [The early years of my life]. Moscow: Tovarishchestvo Tipografii A.I. Mamontova.

14. Goethe, J.W. (1978) Sobr. soch.: v 10 t. [Collected works: in 10 volumes]. Vol. 7. Moscow: Goslitizdat. pp. 7-504.

15. Volkov, I.O. (2019) Uil'yam Shekspir v khudozhestvennom mire I.S. Turgeneva ("Gamlet" $i$ "Korol' Lir") [William Shakespeare in the artistic world of I.S. Turgenev ("Hamlet" and "King Lear")]. Philology Cand. Diss. Tomsk.

16. Schlegel, A. (1817) Über dramatische Kunst und Literatur. Vorlesungen. Teil 3. Heidelberg.

17. Shakespeare, W. (1837) Gamlet [Hamlet]. Translated from English by N.A. Polevoy. Moscow.

18. Morozov, M.M. (1954) Izbrannye stat'i i perevody [Selected articles and translations]. Moscow: GIKhL.

19. A.G. [Herzen, A.A.] (1889) Iz perepiski nedavnikh deyateley: (Materialy dlya istorii russkogo obshchestva) [From the correspondence of recent public figures: (Materials for the history of Russian society)]. Russkaya mysl'. 12. pp. 12-21.

20. Semenko, I.M. (1959) Primechaniya [Notes]. In: Zhukovskiy, V.A. Sobr. soch.: $v 4 t$. [Collected works: in 4 vols]. Vol. 2. Moscow; Leningrad: GIKhL. pp. 451-485.

21. Zhukovskiy, V.A. (1999-cont.) Polnoe sobranie sochineniy i pisem: $v 20 t$. [Complete works and letters: in 20 volumes]. Moscow: YaRK.

22. Yanushkevich, A.S. (2006) V mire Zhukovskogo [In the world of Zhukovsky]. Moscow: Nauka.

23. Grigor'ev, A.A. (1980) Vospominaniya [Memories]. Leningrad: Nauka.

24. Manuscript Department of Russian National Library. Fund 795. Item 9. P. 1-7 rev.

25. Shakespeare, W. (1861) Gamlet [Hamlet]. Translated from English by A.I. Kroneberg. Moscow.

26. Bukhshtab, B.Ya. (1935) Sud'ba literaturnogo nasledstva A.A. Feta [The fate of A.A. Fet's literary heritage]. In: Literaturnoe nasledstvo [Literary heritage]. Vols 22-24. Moscow: Zhur.-gaz. ob"edinenie pp. 561-602. 